УДК 633.34:632.983.3

(C) 2013

Новицька Н. В., кандидат сільськогосподарських наук, Пилипчук М. Ю., магістр

Національний університет біоресурсів і природокористування України

Ситар О. В., кандидат біологічних наук

Навчально-науковий центр «Інститут біології»,

Київський національний університет ім. Тараса Шевченка

\title{
ВРОЖАЙНІСТЬ ЯК ІНТЕГРАЛЬНИЙ ПОКАЗНИК ЕФЕКТИВНОСТІ ЗАСТОСУВАННЯ НАНОМЕТАЛІВ У ТЕХНОЛОГІЇ ВИРОЩУВАННЯ СОЇ
}

\section{Рецензент - кандидат сільськогосподарських наук В. М. Рожко}

\begin{abstract}
Висвітлено результати досліджень врожайності сої на чорноземах типових Лісостепу Украӥни залежно від способу застосування та концентрації багатокомпонентного комплексного розчину наночасток металів. Встановлено, що в технології вирощування сої ефективною є обробка насіння до сівби розчином нанометалів у концентрації 240 мг/л та додаткове обприскування посівів у фазу бутонізачіі. Використання нанометалів для передпосівної обробки насіння сої у концентрації 240 мг/л із нормою витрати 0,1 л/m насіння й додаткове обприскування посівів розчином у концентрації 240 мг/л у фазу бутонізації на фоні внесення мінеральних добрив за норми $N_{60} P_{60} K_{60}$ забезпечує зростання врожайності культури на 1,5-2,5\%.
\end{abstract}

Ключові слова: соя, наночастки металів, мінеральні добрива, урожайність.

Постановка проблеми. Сучасні тенденції світового сільськогосподарського виробництва спрямовані на екологізацію технологій вирощування рослинної продукції. Враховуючи нагальну необхідність переорієнтації сільського господарства нашої держави на стандарти Європейського ринку, ведеться всебічна розробка та впровадження в практику парадигми біологізації інтенсифікаційних процесів у рослинництві $[2,11$, 12]. Зацікавленість до формування екологічно збалансованих агроценозів та підвищення адаптивного потенціалу агрокультур в існуючих системах сільськогосподарського виробництва за останні роки значно зросла. У рамках глобальної теорії органічного землеробства, створювані агроекосистеми повинні бути не лише високопродуктивними, але й екологічно стійкими, володіти здатністю перепрограмовувати онтогенетичні процеси рослин відповідно до різких коливань погодних умов та дії антропогенних чинників для отримання екологічно чистої продукції [8]. Системне дослідження реакцій-відповідей рослин у модифікованих умовах довкілля, тобто за умов зміни кліматичних чинників, трансформа- ції 3 превалюванням деградаційних процесів грунтових та водних систем, забруднення їх різноманітними полютантами свідчить про доцільність використання наноелементів для оптимізації адаптивних стратегій агрокультур та забезпечення сталості їх продукційних параметрів [1].

Аналіз основних досліджень і публікацій, у яких започатковано розв'язання проблеми. Останні дослідження та публікації $[8,11]$ свідчать, що нанорозмірний стан речовини характеризується суттєвою зміною та появою нових властивостей, не притаманних матеріалу у компактному стані. Специфіка наноструктурного стану речовини відображена зокрема у термодинамічних характеристиках, коли зі зменшенням розміру значно збільшується різниця між моделлю твердої фази, що прийнята в класичній термодинаміці, та реальною наночастинкою, а розподіл на об'ємну та поверхневу складові стає умовним. У роботах російських вчених І. П. Арсентьєвої та М. М. Глущенка зі співавторами відмічається, що в умовах постійної температури та тиску, збільшення вільної енергії Гіббса наночасток відбувається за рахунок значного росту площі поверхні або поверхні розподілу фаз у наноструктурованому матеріалі $[1,2]$.

Встановлено, що завдяки великій площі поверхні всі наноматеріали володіють значною поверхневою енергією - збільшеною принаймні на три порядки по відношенню до компактного матеріалу, тим самим знаходячись у нестабільному або метастабільному стані та схильні до утворення агломератів. Використання нанорозмірних біогенних металів сумісно з органічними сполуками, що мають водорозчинні та мембранотропні властивості, безумовно має перспективу, відкриваючи можливість доносити нанорозмірні частки біогенних металів безпосередньо до живих клітин $[3,10]$.

Наночастки біогенних металів використовують у вигляді водних розчинів, які готують 


\section{СІЛЬСЬКЕ ГОСПОДАРСТВО. РОСЛИННИЦТВО}

перед використанням. Дози їх внесення на 1 т насіння або на 1 га посівів надзвичайно малі, тому важливо, щоб вони були рівномірно розведені у робочому розчині. Для цього маточний неіонний колоїдний розчин наночасток металів розводять водою у співвідношенні 1:100. Науковими дослідженнями С. М. Каленської зі співавторами доведена доцільність спільного внесення пестицидів і розчину наночасток металів, оскільки за цих умов як за передпосівної обробки, так і за обприскування посівів у період вегетації підсилюється ефективність дії протруювачів, фунгіцидів, інсектицидів і гербіцидів $[3,5]$.

Технологічні випробування, проведені в останні роки рядом вітчизняних вчених, свідчать, що розчин наночасток металів сумісний 3 усіма видами NPK - добрив та пестицидами [4, $6,9]$. Використання наночасток біогенних металів компенсує втрати мікроелементів, що виносяться рослинами 3 грунту, підвищує стійкість, оптимізує метаболічні процеси рослин відповідно до умов, що складаються за вегетаційний період за одночасного підвищення якості кінцевої продукції. Крім того використання наночасток металів підвищує ефективність дії основних мікродобрив - азотних, фосфорних та калійних. Застосування препаратів дає змогу отримувати екологічно чисту продукцію.

Мета і завдання досліджень. Мета досліджень - вивчення впливу біологічно-активних препаратів на основі нанорозмірних часток металів на рослини сої для визначення перспективи їх використання в технології вирощування культури.

Завдання досліджень передбачали оптимізацію способу застосування і ефективність концентрації розчину наночасток металів на посівах сої.

Матеріали і методи досліджень. У дослідах вивчали запатентований (патент України на корисну модель №38459) маточний колоїдний розчин комплексу ( $\mathrm{Fe}, \mathrm{Mn}, \mathrm{Mo}, \mathrm{Co}, \mathrm{Cu}, \mathrm{Zn}, \mathrm{Ag}$ ) наночасток металів [7]. Польові дослідження з вивчення впливу колоїдного багатокомпонентного розчину наночасток металів на формування врожаю сої проводили на полях кафедри рослинництва у ВП НУБіП України «Агрономічна дослідна станція». Агротехніка у досліді загальноприйнята для північного Лісостепу. Сою висівали за температури грунту на глибині загортання насіння $10-12{ }^{\circ} \mathrm{C}$, овочевою сівалкою $\mathrm{COH}-4,2$. Загальна площа елементарної ділянки - 84 м², облікової - 52,8 м². Повторність досліду - чотириразова. Норма висіву сої - 700 тис. насінин на 1 га. Для захисту від бур'янів проводили досходові боронування та застосовували суміш гербі- цидів «Арамо» (1,0 л/га) і «Базагран» (2,0 л/га).

3 метою визначення ефективності застосування розчину наночасток металів були поставлені два досліди. В досліді 1 вивчали способи застосування колоїдного розчину наночасток металів у технології вирощування сої. Під передпосівну культивацію вносили мінеральні добрива 3 розрахунку $\mathrm{N}_{30} \mathrm{P}_{30} \mathrm{~K}_{30}$. Висівали рекомендовані для зони Лісостепу сорти сої: ультраранній Аннушка (ПП «Наукова селекційно-насінницька фірма «Соєвий вік», м. Кіровоград) і ранньостиглий Устя (ННЦ «Інститут землеробства УААН», смт. Чабани). Схема досліду включала наступні варіанти:

1) контроль 1 (обробка насіння водою);

2) передпосівна обробка насіння комплексом наночасток металів одинарної концентрації (далі - КНM 1);

3) передпосівна обробка насіння комплексом наночасток металів подвійної концентрації (далі - KHM 2);

4) контроль 2 (обробка насіння водою + обприскування посівів у фазу бутонізації водою);

5) передпосівна обробка насіння комплексом наночасток + обприскування посівів у фазу бутонізації комплексом наночасток металів одинарної концентрації;

6) передпосівна обробка насіння комплексом наночасток + обприскування посівів у фазу бутонізації комплексом наночасток металів подвійної концентрації.

Комплекс наночасток металів для передпосівної обробки насіння застосовували 3 нормою витрати 0,1 л/т (100 мл препарату на 10 л води і для 10 т насіння), для позакореневого підживлення у фазу бутонізації та цвітіння рослин сої готували робочі розчини багатокомпонентного препарату наночасток металів із нормою витати 1 л препарату на 100-300 л води (робочий розчин) i на 1 гектар.

Дослід 2 з вивчення ефективності концентрації розчину наночасток металів на посівах сої включав обробку насіння та обприскування посівів сої розчином комплексу наночасток металів одинарної (120 мг/л) та подвійної (240 мг/л) концентрації. Під основний обробіток грунту вносили гранульований суперфосфат $\left(\mathrm{P}_{2} \mathrm{O}_{5}-19 \%\right)$ і калійну сіль $\left(\mathrm{K}_{2} \mathrm{O}-\right.$ 40 \%) у нормі 60 кг/га д.р. Навесні проводили закриття вологи та вносили аміачну селітру (N$30 \%$ ) у нормах $\mathrm{N}_{30} \mathrm{P}_{60} \mathrm{~K}_{60}, \mathrm{~N}_{60} \mathrm{P}_{60} \mathrm{~K}_{60}$ таN $_{90} \mathrm{P}_{60} \mathrm{~K}_{60}$.

Результати досліджень. Критерієм оцінки ефективності процесів фотосинтезу, біологічної фіксації азоту та формування продуктивності рослин $\epsilon$ показники індивідуальної продуктивності рослин та величина урожайності сої. До- 


\section{СІЛЬСЬКЕ ГОСПОДАРСТВО. РОСЛИННИЦТВО}

слідження способів застосування багатокомпонентного розчину нанометалів у системі удобрення сої (рис. 1) дало змогу виявити найефективніший з них. Так, обробка насіння сої до сівби багатокомпонентним розчином нанометалів у концентрації 240 мг/л і додаткове обприскування посівів у фазу бутонізації комплексом наночасток металів подвійної концентрації на фоні $\mathrm{N}_{30} \mathrm{P}_{30} \mathrm{~K}_{30}$ забезпечує приріст врожаю культури порівняно 3 контрольними варіантами на рівні

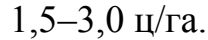

Варіант 6 досліду 1 із застосуванням розчину нанометалів у подвійній концентрації (КНM 2) для передпосівної обробки насіння сої та позакореневого підживлення у фазу цвітіння забезпечив вищу в досліді врожайність культури (на фоні мінерального живлення $\mathrm{N}_{30} \mathrm{P}_{30} \mathrm{~K}_{30}$ ) на рівні 2,44 т/га сорту Устя та 2,49 т/га-сорту Аннушка.

Порівнюючи ефективність застосування наночасток металів із дією мінеральних добрив у системі удобрення культури, нами встановлена позитивна залежність врожайності сої від збільшення концентрації внесеного препарату нано- часток металів. Вищі результати врожайності було отримано за передпосівної обробки насіння сої розчинами наночасток металів - 2,34 т/га (КНM 1) у сорту Аннушка та 2,28 т/га (КНM 2) у сорту Устя (рис. 2).

А найвищі (на варіанті дослідження 3 обробкою насіння КНМ 2 + обприскування посівів КНM 2) - 2,46 т/га у сорту Аннушка та 2,39 т/га - у сорту Устя.

Результати проведених нами досліджень дали можливість встановити, що ефективнішим серед вивчених нами способів застосування багакомпонентного колоїдного розчину металів у технології вирощування сої є використання нанометалів для передпосівної обробки насіння в концентрації 240 мг/л із нормою витати 0,1 л/т насіння та додаткове обприскування посівів у концентрації 240 мг/л у фазу бутонізації на фоні внесення мінеральних добрив у нормі $\mathrm{N}_{60} \mathrm{P}_{60} \mathrm{~K}_{60}$. Даний агрозахід, залежно від норми внесення мінеральних добрив, забезпечує зростання врожайності культури на 1,5-2,5\%.

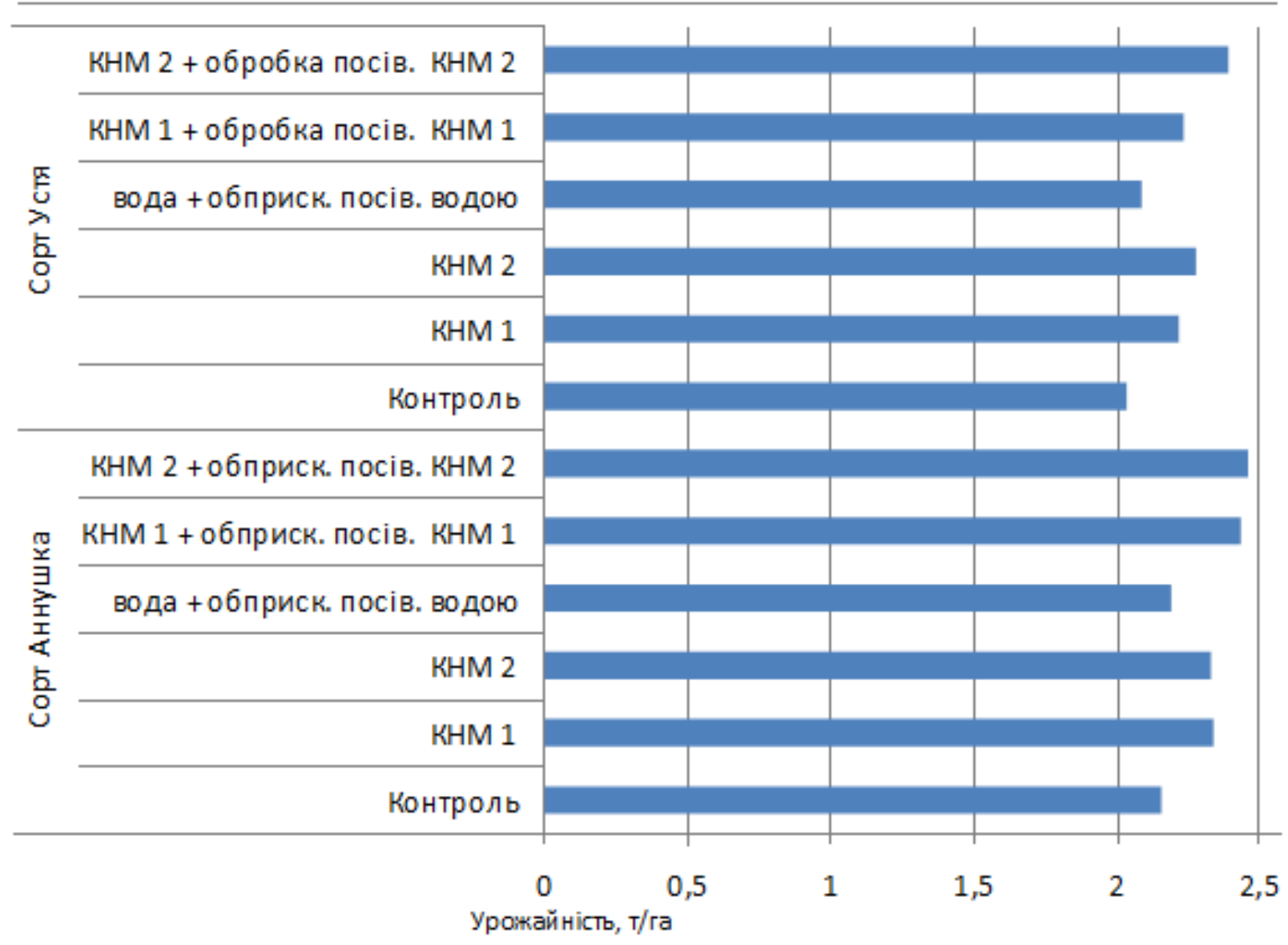

Рис. 1. Урожайність сой залежно від способу застосування комплексного розчину металів, середнс за 2008-2010 рр. (дослід 1) 


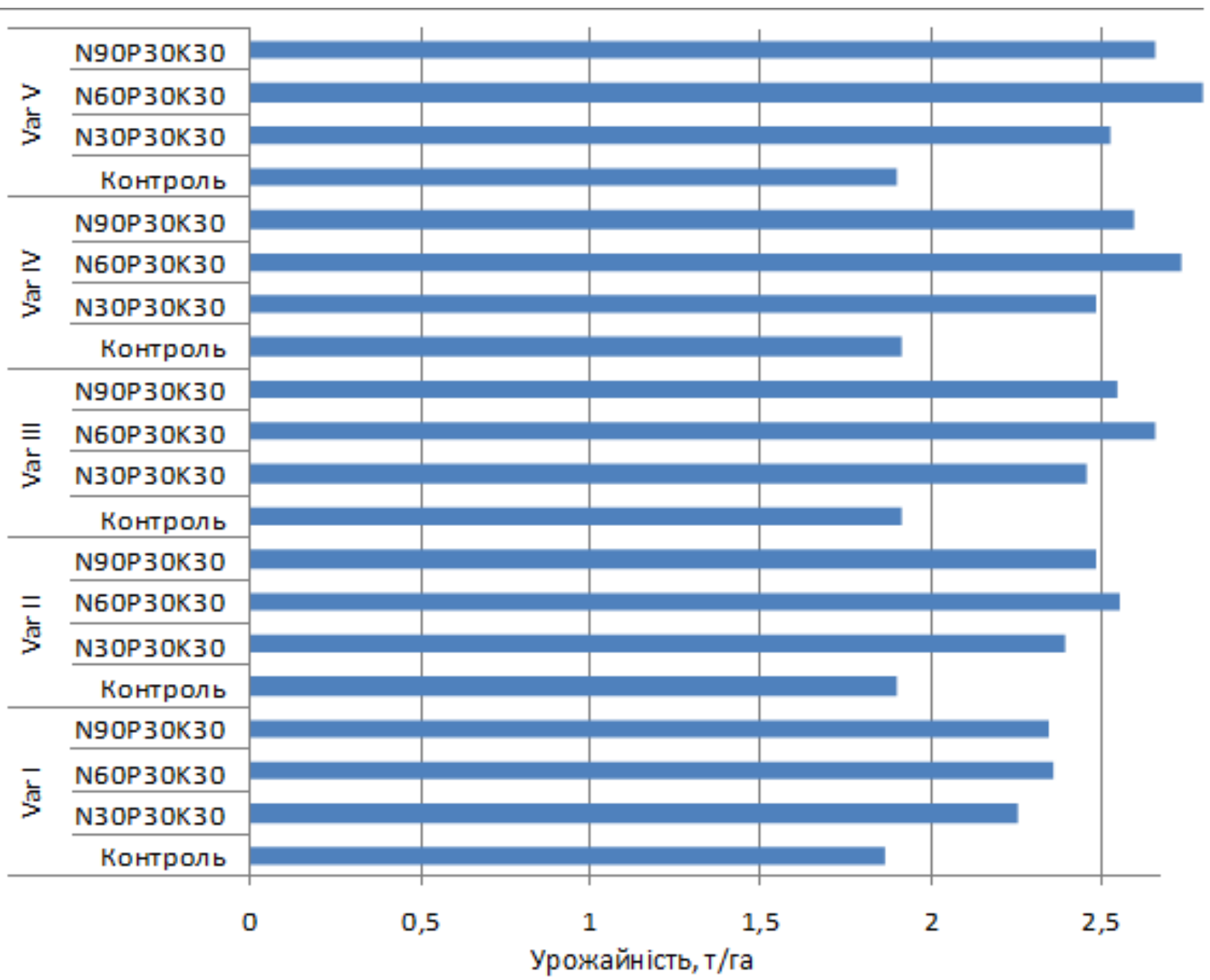

Var I Контроль (без обробки)

Var II Обробка насіння КНМ 1

Var III Обробка насіння КНМ 2

Var IV Обробка насіння та посівів КНМ 1

Var V Обробка насіння та посівів КНМ 2

Рис. 2. Урожайність сой сорту Аннушка залежно від концентрації багатокомпонентного комплексного розчину металів, $\mathrm{m} / 2$ а (дослід 2, середнє за 2008-2010 рр.)

Висновок. У технології вирощування ранньостиглих сортів сої на чорноземах типових малогумусних Лісостепу України багатокомпонентні колоїдні розчини наночасток металів рекомендовано застосовувати для допосівної обробки насіння та підживлення у фазу бутонізації й цвітіння. Для допосівної обробки насіння запатентованим (патент України на корисну модель №38459) маточним колоїдним розчином ком-

\section{БІБЛІОГРАФІЯ}

1. Аттестация и применение наночастиц металлов в качестве биологически активных препаратов / [Арсентьева И. П., Зотова Е. С., Фолманис Г. Э., Глущенко Н. Н., Байтукалов Т. А., Ольховская И. П., Богословская О. А., Балдохин Ю. В., плексу ( $\mathrm{Fe}, \mathrm{Mn}, \mathrm{Mo}, \mathrm{Co}, \mathrm{Cu}, \mathrm{Zn}, \mathrm{Ag}$ ) наночасток металів рекомендовано концентрацію 120 мг/л і $240 \mathrm{мг/л} \mathrm{із} \mathrm{нормою} \mathrm{витрати} \mathrm{0,1} \mathrm{л/т} \mathrm{насіння}$ (100 мл препарату на 10 л води і для 10 т насіння). Для позакореневого підживлення рослин сої слід готувати робочі розчини багатокомпонентного препарату наночасток металів із нормою витати 1 л препарату на 100-300 л води (робочий розчин) і на 1 гектар.

Дзидзигури Э. Л., Сидорова Е. Н.] // Нанотехника. Спец. выпуск «Нанотехнологии - медицине», 2007. - № 2 (10). - С. 72-77.

2. Глущенко Н. Н. Физико-химические закономерности биологического действия высокоди- 


\section{СІЛЬСЬКЕ ГОСПОДАРСТВО. РОСЛИННИЦТВО}

сперсных порошков металлов / Н. Н. Глущенко, О. А. Богословская, И. П. Ольховская // Химическая физика. - 2002. - Т.21, № 4. - С. 79-85.

3. Каленська С. М. Використання біологічноактивних препаратів на основі нанорозмірних часток металів в технології вирощування сої / [С. М. Каленська, Н. В. Новицька, Д. В. Андрієць, Р. М. Холодченко] // Вісник Харківського національного аграрного університету. Серія «Біологія». - Ч. 2. - 2010. - С. 24-32.

4. Каленська С. М. Вплив нанометалів на вміст пігментів у рослинах сої / С. М. Каленська, Н. В. Новицька // Тези доповідей Міжнародної конференції «Актуальні проблеми наук про життя та природокористування», 26-29 жовтня 2011 р., НУбіП України. - С. 8-9.

5. Наукове обгрунтування застосування нанорозмірних біогенних металів у системі удобрення польових культур. Науково-практичні рекомендації / С. М. Каленська, Н. В. Новицька, Л. М. Гончар [та ін.]. - К. : НУбіП України. 2012. -65 c.

6. Новицька Н. В. Використання колоїдного розчину наночасток металів в технології вирощування сої / Н. В. Новицька, Д. В. Андрієць // Міжнародна науково-практична конференція молодих учених, аспірантів і докторантів «Наукові пошуки молоді у третьому тисячолітті», 1213 травня 2010, Білоцерківський Державний аграрний університет. - Електронний ресурс: www.btsau.kiev.ua/ua/text.php?id=115

7. Пат. 38459 України на корисну модель. Маточний колоїдний розчин металів / К. Г. Лопатько,
С. Г. Афтанділянц, О. Л. Тонха, С. М. Каленська; заявник і власник - Національний університет біоресурсів і природокористування України: зареєстр. в Держ. реєстрі патентів України 12.01.2009.

8. Розенфельд Л. Г. Нанотехнології в медицині, фармації та фармакології [Л. Г. Розенфельд, I. С. Чекман, А. I. Тертишна, М. I. Загородний] // Фармакологія та лікарська токсикологія, 2008. - №1-3. - С. 65-71.

9. Cumap O. В. Морфофізіологічні характеристики та урожайність рослин сої за дії неіонних колоїдних розчинів металів / [О.В.Ситар, Н. В. Новицька, Н. Ю.Таран, С. М. Каленська] // Вісник Київського національного університету ім. Т. Шевченка. - Біологія. - № 58. - 2011. C. 44-47.

10.Таран Н. Ю. Вплив азотного живлення та наночасток металів на вміст пігментів у рослинах сої / [Таран Н. Ю., Ситар О. В, Каленська С. М., Новицька Н. В., Гарбар Л. А.] // Таврійський науковий вісник: Науковий журнал. - Вип. 71. - Частина 2. - Херсон : Айлант, 2010. - С. 286-294.

11.Функціональні наноматеріали для потреб сільського господарства / [В. А. Копілевич, В. І. Максін, В. Г. Каплуненко, М. В. Косінов] // Вісник НАУ. - 2008. - № 130. - С. 349-354.

12. Якименко Ю. Місце України в світі нанотехнологій / Ю. Якименко, Т. Наритнюк, В. Цендровський // Дзеркало тижня. - 2008. - № 29. C. 9-15. 